\title{
Effect of incorporation of amaranth on the physical properties and nutritional value of cheese bread
}

\author{
Efeito da incorporação de amaranto nas propriedades físicas e no valor nutritivo do pão de queijo
}

Andréa dos Reis LEMOS ${ }^{1}$, Vanessa Dias CAPRILES ${ }^{2 *}$, Maria Elisabeth Machado PINTO E SILVA ${ }^{1}$, José Alfredo Gomes ARÊAS ${ }^{1}$

\begin{abstract}
At the present celiac disease has no known cure, and its only treatment is a strict lifelong adherence to a gluten-free diet. Cheese bread is a traditional Brazilian product and a safe option for celiacs. However, like other gluten-free breads, it has inherent low levels of fibers and minerals. The objective of this study was to evaluate the effect of incorporation of whole amaranth flour on the physical properties and nutritional value of cheese bread. Amaranth flour was incorporated at 10, 15, and $20 \%$ proportions in different formulations. The increasing amaranth levels darkened the product, reduced specific volume, and increased compression force. Ten percent amaranth-content cheese breads exhibited slight differences in physical properties compared with the controls. These results demonstrated the possibility of incorporating $10 \%$ of whole amaranth flour in the formulation of cheese bread resulting in a product with higher dietary fiber and iron contents and the same level of acceptance as that of the conventional formulation. The aim of this approach is to increase the availability of gluten-free bakery products with added nutritional value contributing to increase the variety of the diet of celiac patients.

Keywords: gluten-free bread; Amaranthus cruentus; celiac disease.
\end{abstract}

\section{Resumo}

A doença celíaca não tem cura e apresenta como único tratamento a dieta isenta de glúten. O pão de queijo, produto tradicional brasileiro, é uma opção para pessoas com doença celíaca. Entretanto, assim como os demais pães sem glúten, possui baixos teores de fibras e minerais. O objetivo deste estudo foi avaliar o efeito da incorporação de farinha de amaranto integral nas propriedades físicas e no valor nutritivo do pão de queijo. A farinha de amaranto foi incorporada em 10, 15 e 20\% das formulações. O aumento dos níveis de amaranto ocasionou: escurecimento do produto, redução do volume específico e aumento da força de compressão. Pães contendo $10 \%$ de amaranto apresentaram ligeiras diferenças nas propriedades físicas em relação ao controle. Os resultados mostram a possibilidade de incorporar $10 \%$ de farinha de amaranto integral na formulação de pão de queijo, resultando em um produto com maiores níveis de fibra alimentar e de ferro e com o mesmo nível de aceitação quando comparado ao convencional. Este tipo de abordagem visa o aumento da disponibilidade de produtos de panificação sem glúten e com valor nutricional agregado, podendo contribuir para uma maior variação da dieta dos celíacos.

Palavras-chave: pão sem glúten; Amaranthus cruentus; doença celíaca.

\section{Introduction}

Celiac disease (CD) is a genetically-based autoimmune disease characterized by life-long intolerance to the ingestion of gluten, a term used to encompass specific storage proteins in wheat (gliadin), rye (secalin), and barley (hordein). Occasionally, oats are contaminated by these other grains during processing and consequently contain gluten (KAGNOFF, 2005). Historically, CD has been considered an uncommon condition, but recent screening studies have indicated that the prevalence of CD could be up to $1 \%$ in populations of European ancestry. Nonetheless, the majority of cases remain undiagnosed (REWERS, 2005).

Celiac disease as yet has no known cure, and the only scientifically proven treatment is strict lifelong adherence to a gluten-free diet. Early recognition of the disease is important because associated disorders and complications, such as nutritional loss, impaired growth and psychomotor development, osteoporosis, anemia, and gastrointestinal cancers can be prevented by adherence to dietary therapy (REWERS, 2005). Compliance with dietary treatment is often difficult due to the need for change in eating habits, acquisition and preparation of products that not part of family dietary habits, and lack of gluten-free industrial products (LEE; NEWMAN, 2003).

Amaranth grain is a highly nutritious gluten-free pseudocereal. Its use in food products is desirable to increase provision of nutrients usually lacking in the celiac diet (KUPPER, 2005). Amaranthus cruentus L. grain contains $60 \%$ starch, $15 \%$ protein, $13 \%$ fiber, $8 \%$ lipids, and $4 \%$ ash (CAPRILES et al., 2008a). Amaranth grain also contains minerals in higher amounts than those of most cereal grains

Received 16/4/2010

Accepted 27/1/2012 (004804)

${ }^{1}$ Departamento de Nutrição, Faculdade de Saúde Pública, Universidade de São Paulo - USP, Av. Doutor Arnaldo,715, Cerqueira César, CEP 01246-904, São Paulo, SP, Brasil

2 Universidade Federal de São Paulo - UNIFESP, Av. Ana Costa, 95, CEP 11060-001, Santos, SP, Brasil, e-mail: vanessa.capriles@unifesp.br

${ }^{*}$ Corresponding author 
(GAMEL et al., 2006). Some research has shown the feasibility of amaranth grain usage in gluten-free products such as biscuits (TOSI; CIAPPINI; MASCIARELLI, 1996), cookies (MARCÍLIO; AMAYA-FARFAN; SILVA, 2005), snacks, cereal bars, and breads (CAPRILES, 2009).

Cheese bread is a traditional Brazilian product which has high acceptability in the market and presents international market expansion (SILVA; GARCIA; FERREIRA, 2003). Cheese bread has no gluten in its composition (PEREIRA et al., 2005). However, like other gluten-free bakery products, it is made from refined flour and starches, and therefore has low levels of fiber and minerals (GALLAGHER; GORMLEY; ARENDT, 2004). The objective of this study was to evaluate the effect of the incorporation of whole amaranth flour on the physical properties and nutritional value of cheese bread.

\section{Materials and methods}

\subsection{Formulation and processing of cheese bread}

Amaranthus cruentus grains were purchased from a local producer in Brasília, Brazil. Amaranth flour was prepared by grinding grains with a hammer mill (MML 100 - Astecma, Grinding Equipment Ltd.) to a particle size of $<0.250 \mathrm{~mm}$. The ingredients for preparing the cheese bread were purchased from the local market.

The control formulation was defined after preliminary tests. Subsequently, 10.6, 16.8 , and $21.5 \mathrm{~g} .100 \mathrm{~g}^{-1}$ of whole amaranth flour were added to the control formulation in order to obtain 10,15 , and $20 \%$ amaranth-enriched baked loaves, respectively. These quantities were defined taking into account the total weight of each formulation and $10 \%$ bake loss (observed in baking preliminary tests).

The amount of ingredients in the formulations of cheese breads was proportionally reduced to allow the addition of amaranth flour, except for the formulations containing 15 and $20 \%$ amaranth, which required an increase in the amount of water resulting in homogeneous dough.

As shown in Table 1, the difference in cheese breads formulations was the amount of all ingredients.

Table 1. Cheese bread formulation with different whole amaranth flour content.

\begin{tabular}{lccrr}
\hline \multirow{2}{*}{$\begin{array}{c}\text { Ingredients } \\
\left(\mathrm{g} .100 \mathrm{~g}^{-1}\right)\end{array}$} & \multicolumn{4}{c}{ Whole amaranth flour content (\%) } \\
\cline { 2 - 5 } & \multicolumn{1}{c}{0} & \multicolumn{1}{c}{10} & \multicolumn{1}{c}{15} & \multicolumn{1}{c}{20} \\
\hline Cassava starch & 28.8 & 26.0 & 22.9 & 21.5 \\
Fermented cassava starch & 12.4 & 11.1 & 9.8 & 9.2 \\
Whole amaranth flour & 0 & 10.6 & 16.8 & 21.5 \\
Water & 5.7 & 4.5 & 8.5 & 8.3 \\
Soy oil & 15.1 & 13.7 & 11.8 & 11.2 \\
Salt & 1.7 & 1.5 & 1.3 & 1.2 \\
Eggs & 15.2 & 13.6 & 12.0 & 11.3 \\
Cheese & 21.1 & 19.0 & 16.9 & 15.8 \\
\hline
\end{tabular}

$0,10,15$ and $20 \%$ refer to cheese bread prepared with different whole amaranth flour content.
Cassava starch, fermented cassava starch, whole amaranth flour, and salt were weighed, homogenized, and scalded with a mixture of boiling water and oil. The dough was left at room temperature for 25 minutes until the mixture reached a temperature of around $25-30{ }^{\circ} \mathrm{C}$. Subsequently, previously beaten eggs, and cheese were added to the dough. The dough was divided into small cylindrical portions of $25 \mathrm{~g}$, molded by hand, and baked at $180{ }^{\circ} \mathrm{C}$ for 15 minutes in a preheated oven. After baking, the cheese breads were removed from the oven and left to cool at room temperature for 1 hour. Next, it was packed in plastic bags and stored at room temperature in a dry place until analysis.

\subsection{Experimental design}

A total of 20 breads were prepared for treatments with 0 and $10 \%$ of amaranth and 23 breads for treatments with 15 and $20 \%$ of amaranth. Three random units were used for specific volume and color analysis. A further three random units were used for moisture evaluation, and five random units were used in texture evaluations. One unit was used for the photographs.

\subsection{Physical properties}

After cooling, the loaves were weighed, and the loaf volume measured by millet-seed displacement. The loaf specific volume (volume $\left[\mathrm{cm}^{3}\right] /$ weight $[\mathrm{g}]$ ) was calculated.

Texture was evaluated by compression strength testing, 1.5 hours post baking using a texture analyzer (TA-XT2i, Stable Micro Systems, Surrey, UK). A cylindrical probe ( $75 \mathrm{~mm}$ in diameter) was used at a speed of $2 \mathrm{~mm} / \mathrm{s}$ and strength of $10 \mathrm{~g}$ to compress the cheese bread to $50 \%$ its original height.

The color of cheese bread was evaluated using a ColorQuest XE equipment (Hunter Lab, USA) according to the CIE-Lab system. The reading angle was $10^{\circ}$, and the standard illuminant was D65, which corresponds to natural daylight. Measurements were taken for $L$ (lightness/darkness), a (redness/greenness), and $b$ (yellowness/blueness). Total color difference $\left(\Delta \mathrm{E}^{*}{ }_{\mathrm{ab}}\right)$ between the standard and the novel formulations was calculated according to the following Equation 1:

$\Delta \mathrm{E}^{*}{ }_{\mathrm{ab}}=\left[\left(\mathrm{L}^{*}{ }_{1}-\mathrm{L}^{*}\right)^{2}+\left(\mathrm{a}^{*}{ }_{1}-\mathrm{a}^{*}{ }_{2}\right)^{2}+\left(\mathrm{b}{ }_{1}-\mathrm{b}_{2}{ }_{2}\right)^{2}\right]^{1 / 2}$

Moisture content was evaluated according to the AACC Approved Method 44-15A (AMERICAN..., 2000).

\subsection{Sensory evaluation}

Ethical procedures were approved by the Ethic Committee of the Faculty of Public Health, University of São Paulo, São Paulo, Brazil (experimental protocol no 1404).

Sensory acceptability of the cheese bread was determined 20 minutes after baking, at the temperature of $40{ }^{\circ} \mathrm{C}$. Fiftyfour untrained judges recruited from staff and students of the Faculty of Public Health - USP evaluated the color, texture, flavor, and overall acceptability of the control and the 10\% amaranth formulation, which obtained the best results in the physical analysis, on a 9-point hedonic scale (STONE; 
SIDEL, 1985) - ( 1 = extreme dislike, $5=$ neither like nor dislike, 9 = extreme like). To be considered accepted, the cheese bread had to reach the established cut off point (values equal or greater than 6) (MUÑOZ; CIVILLE; CARR, 1992).

The samples were presented as "cheese bread" for the control and "wholemeal cheese bread" for the product containing amaranth. The samples were offered in a monadic and sequential way according to a balanced block design. The samples were placed on white plates and identified with three random numbers. The judges evaluated the samples in a testing area and were instructed to rinse their mouths with water between samples to minimize any residual effect.

\subsection{Estimation of nutritional value}

The nutritional value of the products was calculated based on the composition of the whole amaranth flour and the other ingredients, for which data were obtained from the Brazilian Table of Food Composition - TACO (UNIVERSIDADE..., 2006).

\subsection{Statistical analysis}

The results were expressed as mean values and standard deviation. Student $t$ test or analysis of variance (ANOVA) followed by the Tukey test was performed to determine statistical differences among samples. Pearson's correlation coefficients were calculated between amaranth levels and physical properties, and the correlation significance was assessed using the two-tailed Student $t$ test. Statistical analyses were performed using the SPSS software (SPSS Institute Inc., Cary, NC, USA) adopting a significance level of $\mathrm{p}<0.05$.

\section{Results and discussion}

\subsection{Physical properties} Table 2.

The physical properties of cheese breads are shown in

Increasing amaranth levels were shown to decrease the specific volume of breads $(r=-0.99, \mathrm{p}<0.05)$. The effect of formulations on cheese bread volume is also shown in Figure 1. The addition of amaranth resulted in increased compressive strength of the product (from $34 \mathrm{~N}$ in the control up to 240 to $265 \mathrm{~N}$ in formulations with amaranth). There was no significant difference in texture between the amaranth formulations.

The addition of amaranth flour and consequently the reduction of the remaining ingredients reduced specific volume and increased compression strength of cheese bread. This is due to the fact that cassava starch, eggs, and cheese are important ingredients for the texture and expansion cheese bread. Cassava starches favor cheese bread expansion during baking (PEREIRA et al., 1998, 2004). Fats from eggs and cheese provide greater softness and uniformity of cells and structure of the crumb, which helps in obtaining softer texture (PEREIRA et al., 1998; MACHADO; PEREIRA, 2010).

The greater the amount of amaranth flour in the formulations, the lower the $\mathrm{L}$ values $(\mathrm{r}=-0.97, \mathrm{p}<0.05)$ showing that the breads prepared with higher amount of amaranth were darker than the control. Adding amaranth flour also reduced the $b$ values of bread resulting in a significant difference in total color $\left(\Delta \mathrm{E}_{\mathrm{ab}}\right)$ compared with the control. These effects are shown in Figure 1.

The intrinsic color of whole amaranth flour may have caused the darkening of cheese breads, as observed in cakes (CAPRILES et al., 2008b) and gluten-free sandwich breads (CAPRILES, 2009; ALVAREZ-JUBETE et al., 2010).

\subsection{Sensory acceptability}

Although texture was not significantly different between the amaranth-enriched samples (Table 2), the 10\% amaranthenriched bread was selected for sensory acceptability because, in addition to an attractive appearance, it presents specific volume and color values closer to those of the control cheese bread and (Figure 1).

Regarding the acceptability test, the control and the $10 \%$ amaranth formulations were offered in a monadic way to panelists. Figure 2 shows the mean values of acceptability for the evaluated attributes.

Table 2. Physical properties of cheese breads with different whole amaranth flour content.

\begin{tabular}{|c|c|c|c|c|}
\hline \multirow{2}{*}{$\begin{array}{c}\text { Physical } \\
\text { properties }\end{array}$} & \multicolumn{4}{|c|}{ Whole amaranth flour content (\%) } \\
\hline & 0 & 10 & 15 & 20 \\
\hline Specific volume $\left(\mathrm{cm}^{3} \cdot \mathrm{g}^{-1}\right)$ & $1.48^{\mathrm{a}} \pm 0.06$ & $1.30^{\mathrm{b}} \pm 0.04$ & $1.09^{c} \pm 0.08$ & $0.96^{\mathrm{c}} \pm 0.08$ \\
\hline Compressive strength $(\mathrm{N})$ & $34.51^{\mathrm{b}} \pm 9.91$ & $240.49^{\mathrm{a}} \pm 14.73$ & $264.96^{\mathrm{a}} \pm 10.18$ & $263.83^{\mathrm{a}} \pm 20.01$ \\
\hline \multicolumn{5}{|l|}{ Bread color } \\
\hline $\mathrm{L}^{*}$ & $79.99^{\mathrm{a}} \pm 0.38$ & $71.88^{\mathrm{b}} \pm 0.39$ & $69.68^{c} \pm 0.24$ & $68.75^{\mathrm{d}} \pm 0.23$ \\
\hline$a^{*}$ & $1.03^{c} \pm 0.08$ & $5.56^{\mathrm{a}} \pm 0.97$ & $3.59^{\mathrm{b}} \pm 0.10$ & $3.60^{\mathrm{b}} \pm 0.12$ \\
\hline$\Delta \mathrm{a}^{*}$ & - & -4.53 & -2.55 & -2.57 \\
\hline$\Delta \mathrm{b}^{*}$ & - & 0.20 & 5.41 & 5.84 \\
\hline$\Delta \mathrm{E}_{\mathrm{ab}}$ & - & 9.29 & 11.92 & 12.93 \\
\hline
\end{tabular}

$0,10,15$ and $20 \%$ refer to cheese bread prepared with different whole amaranth flour content. Same letters in row indicate no significant difference between samples ( $\mathrm{p}<0.05$ ). 


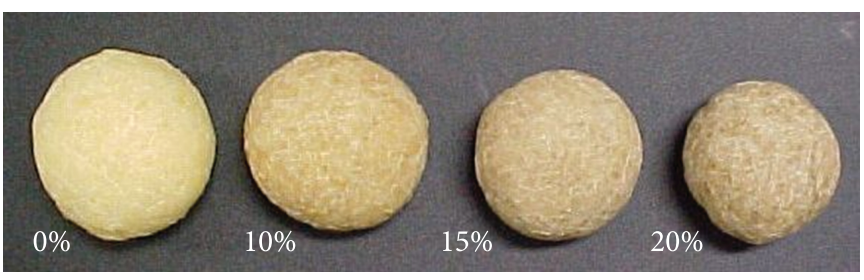

Figure 1. Cheese breads with different whole amaranth flour content.

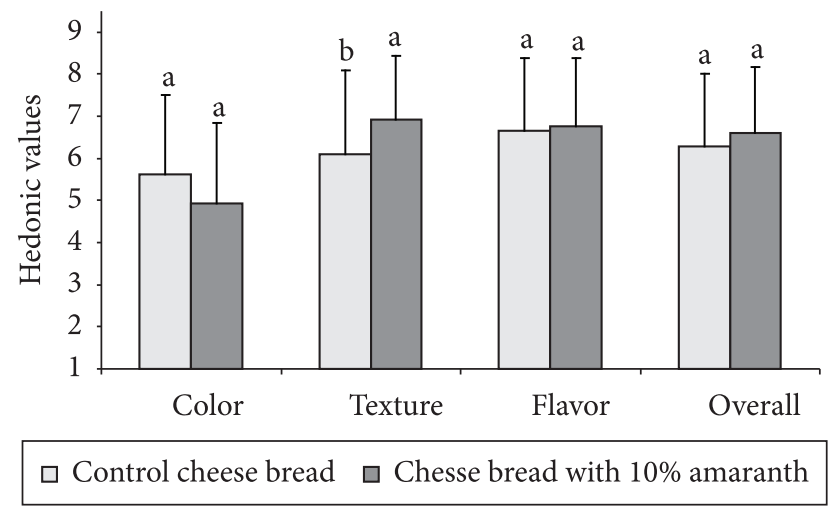

Figure 2. Mean hedonic values assigned for color, texture, flavor, and overall acceptability of 0 and $10 \%$ amaranth-content cheese breads. Different letters indicate significant differences between samples $(\mathrm{p}<0.05)$.

The results demonstrated that it is possible to incorporate $10 \%$ whole amaranth flour in cheese bread while retaining product color, flavor, and overall acceptability. The sample containing $10 \%$ amaranth showed higher acceptability in terms of texture. According to the panelists, the formulation was less oily than the standard, probably due to the lower amount of oil, cheese, and egg used; ingredients which contribute to the oiliness of cheese bread.

Muñoz, Civille and Carr (1992) consider a score of six on the nine point hedonic scale as a quality threshold for food products. Although the product containing amaranth did not attain this score for color, there was no statistically significant difference in color acceptability between the formulation with $10 \%$ amaranth and the control. Based on these criteria, 10\% amaranth-content cheese bread has market potential, as shown in Figure 2.

\subsection{Nutritional value}

Table 3 presents the estimation of the nutritional value of the conventional product and 10\% amaranth-content bread.

The incorporation of 10\% amaranth resulted in an increase in some nutrients: $17 \%$ of protein, 18 times the amount of dietary fiber, and triple the amount of iron compared to the control.

According to the Brazilian technical regulation regarding additional nutritional information (BRASIL, 1998), this new product can be considered a source of protein for all population
Table 3. Nutritional value of cheese bread with different whole amaranth flour content.

\begin{tabular}{|c|c|c|}
\hline & \multicolumn{2}{|c|}{ Whole amaranth flour content (\%) } \\
\hline & 0 & 10 \\
\hline Calories (Kcal) & 356 & 356 \\
\hline Moisture (g.100 g-1) & 29.6 & 28.7 \\
\hline Protein $\left(\mathrm{g} .100 \mathrm{~g}^{-1}\right)$ & 5.82 & 6.80 \\
\hline Lipids (g.100 g ${ }^{-1}$ ) & 20.7 & 19.5 \\
\hline Cholesterol (mg.100 g $\left.{ }^{-1}\right)$ & 36.8 & 33.0 \\
\hline Carbohydrates (g.100 g $\left.\mathrm{g}^{-1}\right)$ & 36.6 & 38.5 \\
\hline Dietary Fiber (g.100 g $\left.{ }^{-1}\right)$ & 0.08 & 1.51 \\
\hline Calcium (mg.100 g $\left.{ }^{-1}\right)$ & 140 & 145 \\
\hline Iron $\left(\mathrm{mg} .100 \mathrm{~g}^{-1}\right)$ & 0.64 & 2.42 \\
\hline
\end{tabular}

groups since it provides at least $10 \%$ of the recommended daily intake/ $100 \mathrm{~g}$ of solid food. Similarly, it is a recognized source of iron since it contains $2.42 \mathrm{mg}$ of iron/100 g (higher than that established by legislation, $\left.2.25 \mathrm{mg} .100 \mathrm{~g} \mathrm{~g}^{-1}\right)$.

These results show that is possible to develop a tasty and nutritious gluten-free product enriched with amaranth.

\section{Conclusions}

Based on the aforementioned results, the introduction of $10 \%$ amaranth in cheese breads proved successful, which is evidenced by slight changes in physical properties and absence of negative effects in the sensory quality. The product presented higher amounts of protein, fiber, and iron than those of the conventional formula.

The aim of this approach is to increase the availability of gluten-free bakery products with added nutritional value contributing to increase the variety of the diet of celiac patients.

\section{Acknowledgements}

The authors are grateful to the nutritionist Ana Paula Gines Geraldo for technical assistance and suggestions during product development and to the volunteers who constituted the sensory panel. This study was financially supported by the State of São Paulo Research Foundation (FAPESP).

\section{References}

ALVAREZ-JUBETE, L. et al. Baking properties and microstructure of pseudocereal flours in gluten-free bread formulations. European Food Research and Technology, v. 230, n. 3, p. 437-445, 2010. http://dx.doi.org/10.1007/s00217-009-1184-z

AMERICAN ASSOCIATION OF CEREAL CHEMISTS - AACC. Approved Methods of the American Association of Cereal Chemists. 10. ed. AACC, 2000.

BRASIL. Portaria no 27, de 13 de janeiro de 1998. Regulamento técnico referente à informação nutricional complementar. Diário Oficial da República Federativa do Brasil, Brasília, DF, 16 jan. 1998. Seção 1, parte 1 . 
CAPRILES, V. D. et al. Effects of processing methods on amaranth starch digestibility and predicted glycemic index. Journal of Food Science, v. 73, n. 7, p. 160-164, 2008a. PMid:18803711. http://dx.doi. org/10.1111/j.1750-3841.2008.00869.x

CAPRILES, V. D. et al. Physical and sensory properties of regular and reduced-fat pound cakes with added amaranth flour. Cereal Chemistry, v. 85, n. 5, p. 614-618, 2008b. http://dx.doi.org/10.1094/ CCHEM-85-5-0614

CAPRILES, V. D. Otimização de propriedades nutricionais e sensoriais de produtos à base de amaranto enriquecidos com frutanos, para intervenção em celíacos. 2009. $198 \mathrm{f}$. Tese (Doutorado em Ciências)-Faculdade de Saúde Pública, Universidade de São Paulo, São Paulo, 2009. PMCid:2668879.

GALLAGHER, E.; GORMLEY, T. R.; ARENDT, E. K. Recent advances in the formulation of gluten-free cereal-based products. Trends in Food Science and Technology, v. 15, n. 3-4, p. 143-152, 2004. PMid:21299575. http://dx.doi.org/10.1016/j.tifs.2003.09.012

GAMEL, T. H. et al. Effect of seed treatments on the chemical composition of two amaranth species: oil, sugars, fibers, minerals and vitamins. Journal of the Science of Food and Agriculture, v. 86, n. 1, p. 82-89, 2006. http://dx.doi.org/10.1002/jsfa.2318

KAGNOFF, M. Overview and pathogenesis of celiac disease. Arquivos de Gastroenterologia, v. 128, n. 4, p. 10-18, 2005.

KUPPER, C. Dietary guidelines and implementation for celiac disease. Arquivos de Gastroenterologia, v. 128, n. 4, p. 121-127, 2005.

LEE, A.; NEWMAN, J. Celiac diet: its impact on quality of life. Journal of the American Dietetic Association, v. 103, n. 11, p. 1533-1535, 2003. PMid:14576723. http://dx.doi.org/10.1016/j. jada.2003.08.027

MACHADO, A. V.; PEREIRA, J. Efeito do escaldamento nas propriedades tecnológicas e reológicas da massa e do pão de queijo.
Ciência e Agrotecnologia, v. 34, n. 2, p. 421-427, 2010. http://dx.doi. org/10.1590/S1413-70542010000200021

MARCÍLIO, R.; AMAYA-FARFAN, J.; SILVA, M. Avaliação da Farinha de Amaranto na Elaboração de Biscoito sem Glúten do Tipo Cookie. Brazilian Journal of Food Technology, v. 8, n. 2, p. 175-181, 2005.

MUÑOZ, A.M.; CIVILLE, V.G.; CARR, B.T. Sensory evaluation in quality control. New York: Van Nostrand Reinhold, 1992.

PEREIRA, A. J. G. Fatores que afetam a qualidade do pão de queijo. Belo Horizonte: CETEC, 1998.

PEREIRA, J. et al. Função dos ingredientes na consistência da massa e nas características do pão de queijo. Ciência e Tecnologia de Alimentos, v. 24, n. 4, p. 494-500, 2004. http://dx.doi.org/10.1590/ S0101-20612004000400003

PEREIRA, J. et al. Comparação entre a composição química determinada e a declarada na embalagem de diferentes marcas de pão de queijo. Ciência e Agrotecnologia, v. 29, n. 3, p. 623-628, 2005. http://dx.doi. org/10.1590/S1413-70542005000300017

REWERS, M. Epidemiology of celiac disease: What are the prevalence, incidence, and progression of celiac disease? Arquivos de Gastroenterologia, v. 128, n. 4, p. 47-51, 2005.

SILVA, M. R.; GARCIA, G. K. S.; FERREIRA, H. F. Caracterização química, física e avaliação da aceitação de pão de queijo com baixo teor energético. Alimentos e Nutrição, v. 14, n. 1, p. 69-75, 2003.

STONE, H.; SIDEL, J. L. Sensory Evaluation Practices. London: Academic Press, 1985.

TOSI, E. A.; CIAPPINI, M. C.; MASCIARELLI, R. Utilización de la harina integral de amaranto (Amaranthus cruentus) en la fabricación de galletas para celiacos. Alimentaria, n. 269, p. 49-51, 1996.

UNIVERSIDADE ESTADUAL DE CAMPINAS - UNICAMP. Tabela brasileira de composição de alimentos - TACO. 2. ed. versão 2. Campinas: UNICAMP/NEPA, 2006. 